\title{
Developing a Competency-Based Credentialing Framework for National Human Resource Development
}

\author{
Vijay Krishna, American National Standards Institute (ANSI)
}

The United Nations has frequently highlighted the role of human resource development as a remedy for undeveloped and underdeveloped countries to overcome their economic deficits. In the last two decades, there has been a growing interest in applying national human resource development (NHRD) for capacity building and economic growth. However, much of the focus of NHRD has been on structures and delivery rather than on outcomes, competency evaluation, and performance. Historically, countries have relied on educational offerings to supply human capital. There is a growing concern that the educational world is not preparing people for the 'newer' jobs. This disconnect between education and employment has led to an increased emphasis on industry aligned credentialing systems. Based on the premise that performance-based assessments are integral to a competency-based education system, this paper links education and employment by industryrecognized personnel certification and presents a credentialing framework to support NHRD. The framework integrates all credentials from high school diplomas to degrees, apprenticeships, vocational training, and certification. The implications for NHRD are tremendous considering the impact on economic development.

Key words: credentialing, certification, workforce development, national HRD

\section{Introduction}

In a knowledge economy, the socio-economic development of a nation largely depends on the quality of its national human capital. People with knowledge are replacing land, machinery, and capital as a nation's primary asset, and without knowledge workers, the other resources are largely unproductive (Drucker, 1999). As per the McKinsey Global Institute (2014), knowledgeintensive flows account for half of the global flows and are growing 1.3 times the rate of labour-intensive goods flow. Countries such as Japan and South Korea have developed thriving economies in spite of limited physical resources by focusing their efforts on human capital development. In the industrial age, the key drivers for economic growth were production and automation. However, in modern times, people have come to occupy a central place in national economic development.

The skills of the workforce are going to be the competitive weapon of the 21 st century. Brainpower will create new technologies, but skilled labour will be the arms and legs that allow one to employ the new product and processing technologies that are being generated. Skilled people become the only competitive advantage (Warner, 2000, p. 752).

Recognizing the importance of human resource development to national economic development, several countries have formulated national human resource development (NHRD) policies to develop a system that will improve the quality of its national human capital. McLean (2004) 
defines NHRD as a national, well-planned investment with the potential to accentuate the human capital of a country and facilitate the attainment of a nation's economic and social goals. While there are considerable differences among countries in how they implement NHRD, which could vary from centralized NHRD to government-initiated NHRD, to decentralized/free market NHRD - there are significant similarities in what these NHRD initiatives include. The activities that fall under the purview of NHRD include: "education and training issues that are cast very widely to include basic education, industrial training, productivity and equity in labour forces and workplaces, creation of comparable labour market data, lifelong learning, and management development" (Zanko \& Ngui, 2003, p. 13).

In the past, countries have relied on educational institutions to supply human capital, and a college degree served as a passport to a good paying job. However, in current times this model is not meeting the needs of employers and job seekers due to the fundamental differences in the orientation of the worlds of education and employment.

The worlds of education and employment are different, each with a different set of priorities, motivations, and purposes, which could be referred to as "employment logic" and "educational logic." In the logic of employment, employers are interested in what people need to do, how they will do it, and how well they do it. They are interested in outcomes. In the logic of education, education professionals are interested in what people learn, how they will learn it, and how the quality and content of learning will be assessed. Education traditionally uses a language of input (syllabus, subject), process (teaching/learning methods), and assessment (Fretwell, Lewis, \& Deij, 2001, p. 31).

Because of the fundamental differences between education and employment logic, there is a growing concern that the educational world is not preparing people with employable skills. While $96 \%$ of the chief academic officers believe that graduates have the requisite skills for the workforce, only $11 \%$ of business leaders think so (Weise, 2014). To bridge this disconnect, educational institutions are moving towards competency-based credentialing. The concept of competency requires mastery of technical, interpersonal, and methodological skills that include the ability to learn on one's own, to pursue lifelong learning, and to cope with risk and change (World Bank, 2003). The movement from a 'seat time'-based educational system to an outcome-based credentialing system creates flexibility and allows students to acquire skills and demonstrate mastery based on their individual learning needs.

Emphasis on competency-based education has resulted in increased attention on personnel certification to assess the job-related competencies of students and young adults. According to Kuczera and Field (2013), certifications are an essential means of skill acquisition. The American Board of Nursing Specialties (2005) reported that 58 percent of nurse managers reported seeing a positive performance difference between certified nurses versus their non-certified colleagues (Eisemon \& Cline, 2006). Research studies have found that certified nurses display greater confidence, decision making, and detect complications more readily (Eisemon \& Cline, 2006). Hsu and Yancey (2015) in the survey research involving 422 HR professionals found that certified HR professionals received more pay (even after controlling for level of education and years of HR experience) and had higher occupational commitment than uncertified HR professionals. A certification is an attractive option for worker-learners who are looking to avoid the normal constraints of educational programmes based on 'seat time' to acquire job-related competencies. Certification is an indicator of the knowledge and skills attained by an individual through measurement, assessment, and documented skills acquisition. Assessment is the process of measuring and documenting an individual's competence to perform required job functions 
based on a job/practice analysis. Certifications are not meant to replace traditional educational programmes; instead, they offer an alternate pathway for career and professional development especially for students who are not able to afford the high cost of a university degree programme or want to benefit from the flexibility associated with certifications. Apart from offering an alternate pathway to the traditional educational system, personnel certification enables veterans, displaced workers, and parents who take time off to raise children to re-enter the workforce with new credentials into high demand technical or professional jobs.

The primary purpose of this paper is to propose a framework to develop a competency-based credentialing system to meet the changing needs of learners and employers. The framework is based on the premise that competency development by educational institutions and competency evaluation by industry-recognized certifications ought to be complementary. The paper outlines a pathway to embed certifications based on international quality standards in a competencybased education system to support NHRD. Even though the framework is derived primarily from a North American perspective, its implication for NHRD extends to both developed and developing economies that are faced with the challenge of providing growing population with the skills to leverage new opportunities that have emerged on account of globalization and technological innovation.

The paper is structured as follows; the first part outlines the challenges facing the current education system and the need for a competency-based credentialing. This is followed by a synthesis of literature that supports the relationship between human capital development and personnel certification. The next section describes the international analogues of the U.S. system of certification with illustrations from different geographic regions of the world. The next part describes the proposed model with certifications embedded throughout the credentialing system to make the education system performance oriented and competency-driven. The final section summarizes the implications and directions for HRD.

\section{Problem Statement}

The fast-changing technologies of the Fourth Industrial Revolution is disrupting industries and companies. In fact, the 'future of work' is one of the most debated topics today due to the introduction of robotics, artificial intelligence (AI), and the internet of things (IOT). Even developed countries such as Japan and the U.S. do not have a credentialing system to deal with the disruption happening due to these changes. Japan has maintained its traditional and outdated model of human capital practices for a long time, and as such does not have a good base to develop growing skills and flexible work styles (Ishikura, 2018). The current U.S. credentialing system is dysfunctional and not aligned with the needs of the 21 st century (Connecting Credentials, 2016). "Those hurt the most by the credentialing system are those who have the least" (Connecting Credentials, 2016, p. 2). An increasing number of students and worker-learners do not have access to the higher education required for good-paying jobs. Besides, several dislocated workers who have valuable skills are unable to build new careers due to lack of proper industry-relevant learning opportunities. The current credentialing system does not fully recognize students who have acquired skills through non-traditional forms of education such as experiential learning and apprenticeships. Several surveys have also revealed the struggles employers have with the current credentialing system. Data shows that the U.S. faces a significant skills gap (Connecting Credentials, 2016). 
- 76 percent of CEOs of companies in the Inc. 5000 say that finding qualified people is a major concern for their companies.

- In a survey of 126 CEOs of major U.S. companies conducted by the Business Roundtable and Change the Equation, 97 percent of respondents cited the skills gap as a problem, and 62 percent reported trouble finding applicants for jobs requiring information technology and advanced computer knowledge.

To address these challenges, the U.S. credentialing system needs to be revamped to meet the needs of learners and employers. According to a study by the Corporation for Skilled Workers, "A chaotic patchwork of sub-degree certificates, licenses, and other credentials is offered by a confusing array of industry and occupational groups, third-party validators, and educational providers and systems. No national framework exists for developing and endorsing these credentials" (Corporation for a Skilled Workforce, 2018, p. 3). In the absence of a national framework, countries are working on individual elements of a credentialing system that are largely disconnected. Currently, both developed and developing economies are facing varying degree of skill shortages and skills-mismatch. "HRD has an interest in workforce development and so should have an interest in this problem as it is an increasingly important problem" (Torraco, 2007, p. 347). Workforce development involves promoting economic wellbeing by developing the competence of people.

Certificates and Certification provides one of the most promising routes to the upskilling of the adult population (Kuczera \& Field, 2013). Given the importance of professional certification, this article begins to define its role in NHRD and lays a framework for capacity building especially for countries that are moving away from the conventional human development practices to a skill-based approach to jobs.

\section{Human Development and National Human Resource Development}

The conventional approach to national development has been built around the principle of wealth maximization, from Adam Smith (1976) onwards with focus on making the nation wealthy as a whole without regard to other factors such as income distribution, social justice, sustainable development, public care, and physical and environmental concerns that are central to success of human living. The human development approach is unique as it focuses on expanding people's capabilities and regards economic growth as a means and not an end in itself (Fakuda-Parr, 2003). The concept of human development is based on Amartya Sen's work on capabilities and functionings and provides a strong conceptual foundation for this new paradigm. Sen (1989) defined human development as the process of enlarging a person's "functionings and capabilities to function, the range of things that a person could do and be in her life" (as cited in Fakuda-Parr 2003, p. 303). The concept of human development in developmental economics is significant, as it has shifted "the focus of development economics from national income accounting to people centred policies" (Haq 1995, as cited in Fukuda-Parr 2003, p. 302). Conceptually, this definition of human development is similar to the definition of NHRD as elaborated by McLean (2004), where he states that NHRD is more than just manpower planning or human capital investment and includes considerations such as health, safety, and community. The human development approach shares with other approaches such as NHRD a premise that investing in people's education and health is a powerful means to achieve economic and social progress (FakudaParr, 2003). While NHRD and national human development have similarities concerning 
national developmental goals, they are not the same. National human development defines the goals that are central to development economics; NHRD, on the other hand, focuses on the processes to achieve this goal. In other words, human development can be regarded as the goal of developmental economics and NHRD as the means to achieve it.

\section{Human Capital Theory and Personnel Certification}

The human capital theory (HCT) articulates a positive relationship between investment in education and training and workforce productivity. There is a large body of research carried out by economists such as Schultz (1961) that establishes a clear relationship among education, human capital, and worker productivity. HCT regards education as an investment that yields higher wages and salaries in the future (Sidorkin, 2007). Several reviews of estimates of returns on investment in education from 1950 to 2000 reiterate the importance of HCT (Psacharopoulos \& Patrinos, 2004). "Human capital refers to the 'unique set of abilities and acquired skills' that an individual gains through education and job training that improve employability and earning power" (Gao, Gill, Schmidt, \& Pratt, 2010, p. 25). While education provides general skills that contribute to human capital, there is increasing recognition of the contribution of professionspecific skills to economic growth (Gathmann \& Schönberg, 2010). In this study, HCT is used as the main theoretical framework to link personnel certification and NHRD.

Professional certification with emphasis on developing work-related competencies facilitates skilling of people and thereby contributes to the development of human capital. The Consultative Committee for Professional Management Organizations (CCPMO) found in their economic impact assessment study that the estimated lifetime economic benefit associated with holding professional qualifications and membership of a professional institute is approximately $£ 152,000$ (Chapman, Conlon, \& Muller, 2008). CCPMO represented eight leading professional bodies in business disciplines in the UK with over half a million individual members. Further, the broader economic impact regarding additional tax revenue contributed by an individual with professional qualifications and membership of a professional institute was found to be about $£ 53,000$ in monetary terms. As per the U.S. Department of Education Adult Training and Education 2016 Survey, 31 percent of all labour force participants hold a non-degree credential (Cronen, McQuiggan \& Isenberg, 2017). A non-degree credential includes individuals who have received sub-baccalaureate certificates and two work credentials or certifications (e.g., Cisco Certified Network Associate) and licensure (e.g., medical licence). For 13 percent of the labour force who do not have a degree, the non-degree credential is their only work credential. Among the 13 percent non-degree credentialed labour force participants, 21 percent held a certification.

In many countries, the international analogues to the U.S. system of certification include examination by professional associations. According to Fazekas and Field (2013), in Switzerland, an industry-led, but federally regulated system of professional education and testing is used to upskill adults who have completed an apprenticeship programme. In recent times, the scope of examination has widened to include non-technical professions in the commercial, manufacturing, agricultural, and service related sectors. The examination fulfils multiple purposes to include server as gatekeepers for the profession and a tool for human resource development. In Israel, the examination system is used as a tool for upskilling in more than one hundred professions (Kuczera \& Field, 2012). In the Germanophone countries, qualified apprentices take the examination in entrepreneurship, as well as higher-level skills in the target trade (Kuczera \& 
Field 2013). In Europe, 28 accreditation bodies are signatories to the European co-operation for Accreditation (EA) multilateral recognition arrangement (MLA) for the certification of persons. The corresponding number in the Asia-Pacific region is six, the Inter American Accreditation Council was 36, and the Arab Accreditation Cooperation (ARAC) was 12. The data under table shows the rapid growth across various regions regarding certification bodies for persons, all accredited under the same international standard.

\begin{tabular}{lc}
\hline International Accreditation Forum (IAF) & $\begin{array}{l}\text { Number of personnel certification bodies } \\
\text { accredited to ISO/IEC 17024 }\end{array}$ \\
\hline European Accreditation (EA) & 573 \\
Inter-American Accreditation Council (IAAC) & 36 \\
Arab Accreditation Cooperation (ARAC) & 12 \\
Pacific Accreditation Cooperation (PAC) & 185 \\
\hline
\end{tabular}

Table 1: Number of Accredited Certifications

Number of accredited personnel certification bodies in different regions as per the International Accreditation Forum (2017).

The United Nations Industrial Development Organization (UNIDO) has published a manual that highlights the importance of personnel certification for workforce development as part of the National Quality Infrastructure Project for Nigeria funded by the European Union (UNIDO, 2018). The European Union-Sri Lanka trade-related assistance programme, which seeks to contribute to Sri Lanka's inclusive trade-led growth and regional integration, thereby contributing to poverty alleviation relies among others on personnel certification as per ISO/IEC 17024 to accomplish the project goals.

Traditionally, many countries have relied on a supply-side focus with an underlying assumption that upskilling the workforce would result in the creation of high paying jobs and economic development. Increasingly, there is an emphasis on a demand-led system in which employers play an important role in offering training. In England, there is a move towards making apprenticeships more demand-side oriented where employers play an important role in designing occupational standards (Green \& Hogarth, 2016). The role of certification, quality assurance, employerled policies, and international collaborations are clearly articulated in the U.K. vocational education skills system (Rexworthy, 2015). The U.S. Department of Labor has collaborated with certification bodies so that registered apprentices at the end of their career training programmes can take a national industry certification. The U.S. Department of Labor is also in the process of launching an industry recognized apprenticeship programme (IRAP). Irrespective of the type of credential that is offered (certificate, certification, apprenticeships, degrees, and diplomas), there are certain core elements of quality, competency-based credentialing process:

- A credential should be empirically based, derived from industry needs, and include a structured process to identify the knowledge, skills, and attributes for a specific job/ function.

- All credentials must have a valid assessment process that measures an individual's competencies and assesses their demonstration that they have the knowledge and skills necessary for practice.

- The credential should be developed and operated in an overall quality framework with an emphasis on continuous improvement. 
- Quality credentials also require validation by an independent third party as evidence that the credentialing organization meets established standards. An independent third-party accreditation is an accountability mechanism to ensure the quality and legitimacy of organizations offering credentials

\section{A Competency-based Credentialing Framework for National Human Resource Development}

This paper presents a competency-based credentialing framework for NHRD. Under the framework, different types of credentials from high school diploma to college degrees, certificates, and certifications are linked to various employment opportunities. The proposed framework is based on the following ten assumptions:

(1) The primary function of an educational system is to help students acquire life skills so that they can find good, paying jobs and be part of a productive workforce. The framework does not explicitly address other goals of education that include developing a global mindset, character building, societal values, and good citizenship.

(2) The primary purpose of the workforce development system is to acquire technical and professional skills to improve employability and earning power.

(3) Different learners have different learning needs, and a credentialing system should provide flexibility to meet these divergent needs.

(4) The concept of stacked credentials, whereby people engage in lifelong learning activities and continue to acquire newer credentials to improve their career prospects.

(5) There are alternate routes to achieve professional success by using different types of credentials. While some people would prefer a traditional career pathway that includes acquiring a college or a university degree, others might choose vocational training, apprenticeships, professional certification, and assessment-based training certificates.

(6) Every child must have access to primary and secondary school (K-12, kindergarten to 12th grade) education. For children who are not able to attend school as full-time students due to economic reasons, there should be alternate pathways to acquire a high school diploma while being part of the workforce.

(7) A skilled workforce will have access to jobs, which in turn will lead to economic development.

(8) The system of professional certification is not very well developed uniformly across all countries. For instance, almost all professional societies in the United States offer certification, whereas in most developing countries professional certification is virtually non-existent. These countries rely solely on education and vocational training for their workforce development.

(9) Personnel certification may not be relevant to all the individuals in an economy just as not everyone needs a university or college degree to find meaningful employment. Personnel certification, like a college degree or vocational training, should be an essential component of the credential framework for workforce development. 
(10) Even though the framework proposed in this paper is derived primarily from a North American perspective, it has application in both developed and developing economies that are working towards a competency-based credentialing system to address 21st-century workforce issues.
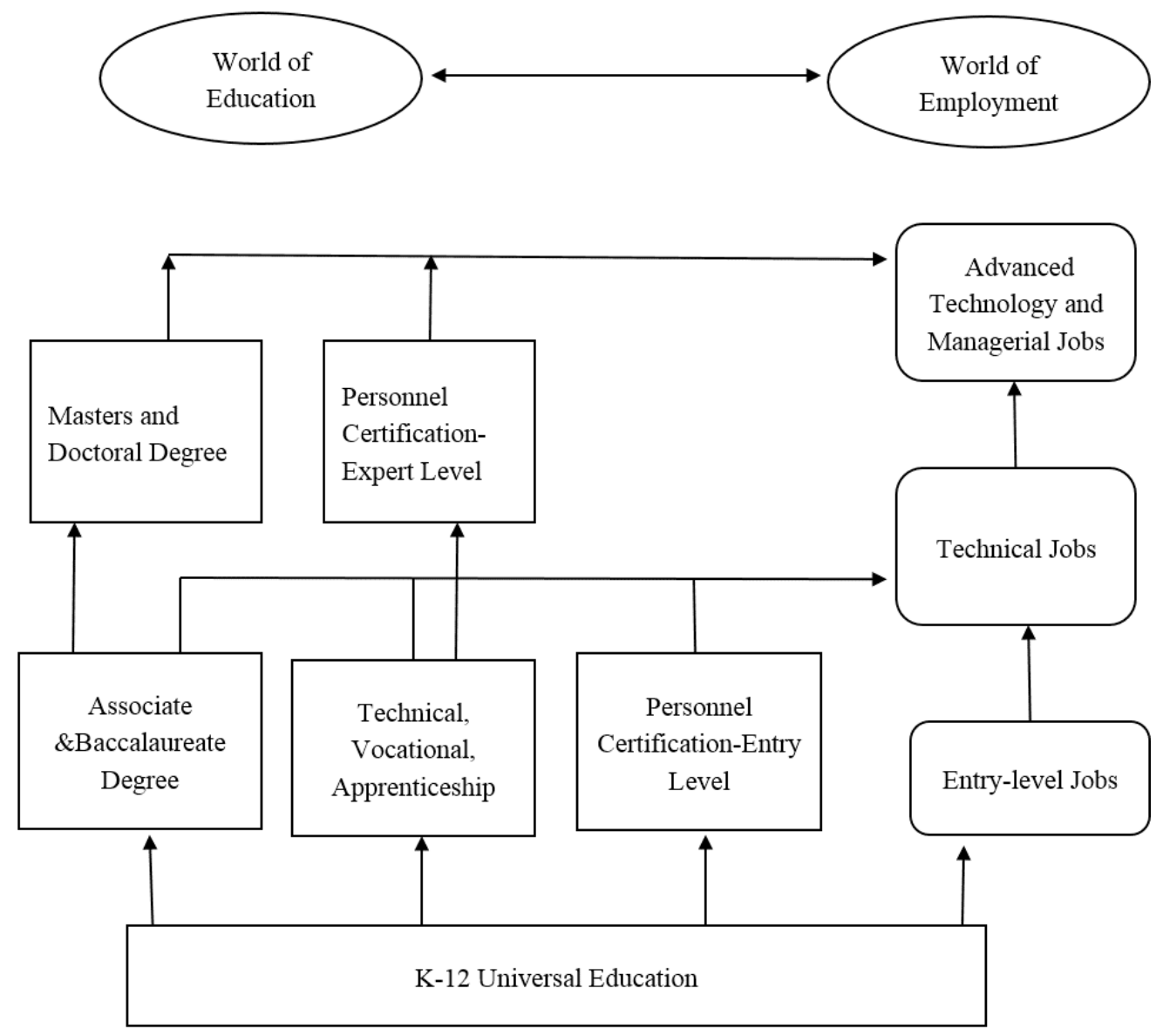

Figure 1: A Credentialing Framework for National Human Resource Development

Under the proposed model, certifications are embedded throughout the credentialing system to make the education system performance oriented and competency-driven. While a college degree continues to generate the best long-term earning and employment outcomes of all credentials (Belfield \& Bailey, 2011), embedding certifications into a degree programme allows students to obtain both credentials at the same time. As per the proposed framework, schools should be organized around the principle of early learning. All educational offerings starting from K-12 to an advanced university degree should be designed on a set of clear learning objectives and evaluation of learning outcomes. According to McCarthy (2016) from the New America Foundation, "If we think about what that outcome is, that could change how programmes and pathways are constructed because we are thinking of preparing people for the workforce as a major goal" (p. 82). Fair, valid, and reliable assessments are essential to 
support a competency-based educational system. Traditionally, educational institutions have relied on norm-referenced assessments to evaluate students. Under this approach, students are assessed in comparison with other students. This system does not reveal whether a student has demonstrated the required competence to practice. However, in a criterion-referenced grading, students are evaluated based on objective standards of competence rather than comparison to other students.

In the current education system, there is too much testing but too little assessment of students learning. A typical test offered in schools and colleges has been created from a positivist perspective with emphasis on one right way to do things. These tests operate under stringent rules, without much freedom for creativity or innovation. The knowledge and skills are tested from a perspective of exploitation, rather than exploration. Wheatley and Kellner-Rogers (1996) remind us that "life is attracted to order. But how it gets there violates all our rules of good process" (p. 17). This would mean developing alternative assessment techniques based on performance evaluations, portfolios, live case studies, simulations, and experience in the field.

While there could be multiple approaches to develop employability skills, it cannot be accomplished without student involvement. It is vital for students, parents, and educators to understand what constitutes employability skills and incorporate them in the curriculum. This will require critical investment in recruiting and training competent educators who can make a real difference in placing students on a fast learning track. Students entering high school should be encouraged to get industry-recognized certifications that are aligned to their high school curriculum. For example, students enrolled in computer science courses should be encouraged to take an industry recognized IT certification.

Similarly, students seeking advanced biology courses should consider related medical and healthcare certifications in fields such as pharmacy technician certification, medical assistant certification, occupational therapy, and electronic health record certification. Accordingly, students who pass out of high school and want to further their technical skills can pursue advanced training in vocational schools, community colleges, or through an apprenticeship programme. These students should also work toward professional certifications in their field of study to enhance their job prospects.

Under the proposed framework, advanced academic degrees would prepare students for advanced technology and managerial jobs. All students enrolled in a university or college in a degree programme should be encouraged to get the relevant personnel certification in their field. Besides, the educational curriculum must be aligned with the industry skill standards and a job/ practice analysis. This alignment will help bridge the skills gap and facilitate higher employment for students who complete a college or university programme.

\section{Skills, flexibility, and employability are vital aspects of a credentialing framework}

To maximize human resource development, three factors are significant: building a flexible education system, developing and updating needed skills, and enhancing employability (Wang, 2012). A flexible system provides learners with the opportunity to acquire knowledge and skills when they need to do so and in a manner that meets their learning and lifestyle needs. The system also educates them about emerging and newer opportunities for skill development. The system addresses the needs of not only school going children but also importantly adults who are looking to update their skills as lifelong learners. The skills element focuses on outcome-based learning 
for a student to be gainfully employed. Employability refers to the linkage between education and employment such that the worlds of education and employment remain interconnected.

Samuelson (2006) states that the American learning system has two important virtues that support its advanced economy: First, it provides second chances. It tries to teach people when they are motivated to learn, which is not always when they are in high school or starting college. Second, it is job oriented. Community colleges provide training for local firms and offer courses to satisfy market needs. Arguably, the American learning system can provide these two options because it has a very well developed network of personnel certification. This suggests that competencybased credentials have the potential to make a significant impact on NHRD. According to the U.S. Bureau of Labor Statistics, approximately 26 percent of the employed people who are 25 years or over in the United States had a license or certification (Torpey, 2016).

Furthermore, workers with advanced degrees were more likely to be licenced or certified. For example, more than half of professionals with masters, professional, or doctoral degree had one or more of these credentials. Carter (2005) showed that between 2000 and 2003, the number of people seeking a certification nearly tripled. Certifications help overcome the normal constraints of education programmes that require a fixed 'seat time' to acquire a qualification. Consequently, certifications serve very effectively as a vehicle for the assessment of prior learning (Kuczera \& Field, 2013).

A fully developed quality-driven certification framework provides flexibility, skill enhancement, and employability.

\section{Flexibility}

In today's rapidly changing environment, constant upskilling is no longer an option for workers who cannot keep pace with the rapid adoption of new technologies. However, it is practically impossible for workers and employed persons to take extended time off from their jobs and pursue traditional educational programmes. On the other hand, a certification can be attained on a more flexible schedule and be a productive path forward for many more people. A person can acquire new knowledge through a variety of options such as online training, boot camp, or self-study, and by passing a certification examination, demonstrate that they have the required competency to practice. Furthermore, the concept of stacked credentials provides worker-learners with an opportunity to continue to acquire advanced credentials as they obtain higher skills. A graduated sequence of credentials allows them to progress at their own pace over a self-directed lifelong learning path. It is an ideal platform especially for non-traditional worker learners who cannot commit to a long-term educational offering.

\section{Employability}

Integrating employability skills into a competency-based credentialing framework is imperative. In a rapidly changing world, employers continue to highlight the importance of basic employability skills such as critical thinking, problem-solving, communication skills, and creativity. Employability also implies a linkage between education and employment. For far too long, the worlds of education and employment have existed as separate spinning wheels. Education should help students acquire real-life skills that will help them find a job. Employability outcomes are becoming a key performance indicator of universities. For instance, in Britain, the Higher Education Statistics Agency collects and reports national data on publicly 
funded institutions, including employment rate and type of employment outcome. The move to show a return on investment through employment also called 'graduate premium' is strongly correlated with a recent increase in the cost of education (Purcell, 2014). This is also leading to public shift across countries to recognize that graduates are beneficiaries of their education and should contribute to reducing the public subsidy on higher education.

\section{Skills}

The skills dimension relates to helping learners acquire competency to be fully engaged in the economy. Historically, the world of education has divided students into general and vocational tracks, and many education systems favour academic study over skills development (Wang, 2012). Under this system, 'good' students are selected for general education and 'poor' students for vocational education. While there is a greater emphasis in the United States on general education in secondary schools, much of Europe relies on vocational training and apprenticeships. Goldin (2001) notes the essential trade-off between these different approaches: "Formal, school-based education enabled American youths to change occupations over their lifetimes and to respond rapidly to technological change" (p. 277). Arguably, the biggest weakness of the dual track model is that once a student enters the vocational track, the person has minimal opportunity to get back into the general education track. Currently, most countries are experiencing substantial technological and profound economic transformation. These changes require people to upgrade their skills and adapt to market conditions on an ongoing basis. Adapting to these changes is likely to be very difficult for a workforce trained in a narrow, specialized domain. Instead of separating students into general and vocational tracks, the education system should focus on developing both technical and employability skills anchored in a general educational framework.

\section{Competency-based Certification}

The framework outlined in this paper relies on industry-driven competency-based certifications to validate attainment of knowledge, skills, and attributes. Quality has to be a cornerstone of any credentialing system be it school, college, or certification. Despite the increased number of certifications available in the marketplace, the certification world is largely opaque, leaving users unsure of the quality and reliability of organizations offering certifications, as well as of the competencies (if any) being communicated through their credentials. Many certifications are self-declared and do not provide the skills and competencies needed by employers. The U.S. Consumer Financial Protection Bureau found in its recent study that consumers find it almost impossible to distinguish designations concerning quality or legitimacy. The report recommended using quality standards and strengthening 'accountability mechanisms' to foster trust and confidence in certification.

\section{An international standard for certification}

While technology is disrupting the certification eco-system, the transformative powers of these processes will be realized only if these innovations are grounded in quality standards. A standard provides a framework for ensuring quality, transparency, and interoperability. The international standard ISO/IEC 17024, Conformity assessment — General requirements for bodies operating certification of persons, provides a global benchmark for quality certification. During recent years, this standard - developed by the International Organization for Standardization (ISO), 
which represents members from 162 countries - has fundamentally altered the delivery of certifications and created a very strong drive to globalize personnel certification. ISO developed the standard based on the need for public protection by establishing that individuals have the required competency to perform their job. Several government agencies worldwide have recognized the standard as a critical requirement for personnel certification bodies that offer certification in areas related to public health, environment, and national security. There are over 40 agencies worldwide, mostly government or government-approved, that accredit personnel certification bodies based on this standard. The use of a common international standard that is recognized by government agencies, trade associations, industry partners, and professional associations provides a unique opportunity to globalize the certification of persons. Just as the manufacturing and technology innovations in the 1950s were based on the quality movement, the globalization of persons in the 21 st century has to be similarly grounded in a quality certification standard. The following figure provides a simple yet powerful visual of the core elements of a standards-based quality certification programme (Krishna, 2014).

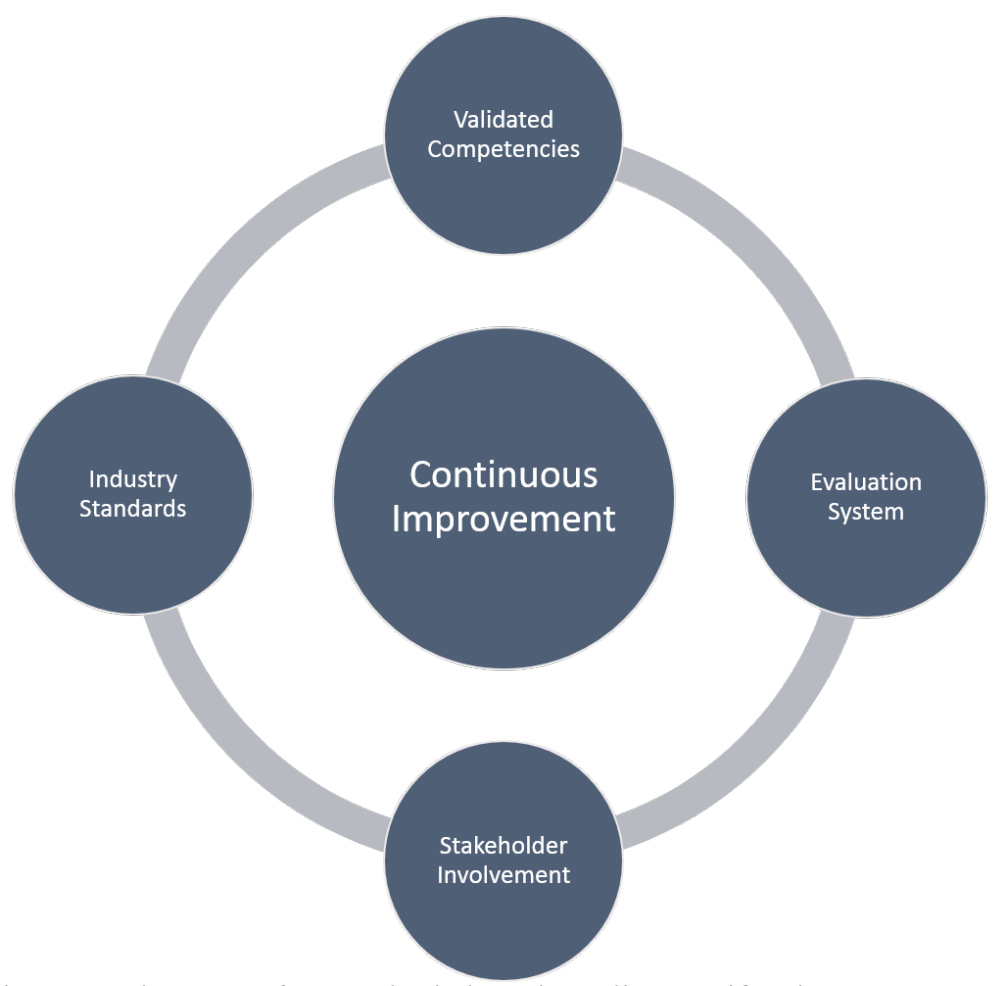

Figure 2: Elements of a Standards-based Quality Certification Programme

\section{Validated competencies}

Competencies are the foundational building blocks in creating a certification programme that must be developed in a systematic manner using an empirically derived process such as job/ practice analysis. The process should involve the key stakeholders and subject matter experts. Competencies denote the knowledge, skills, and abilities that an individual needs to perform the tasks. 


\section{Stakeholder involvement}

To be market relevant, the certification should be developed with the involvement of all key stakeholder groups. High-quality certification requires inputs from business, industry, employers, educators, students, regulators, and consumers.

\section{Evaluation system}

Evaluation is the process of measuring and documenting an individual's competence to perform required job functions. The certification examination must be fair, valid, and reliable. A valid test correctly measures whether an individual has the necessary competencies for the job. Validity is an indicator to establish that the process measures what it is intended to measure, whereas reliability shows that the test consistently measures a person's abilities. The standard requires assessment for not only initial certification but also an assessment of continued competence through a recertification process.

\section{Continuous improvement}

There is a need to systematically review the required competencies and skill standards to ensure that they remain updated and relevant to the needs of the changing market. The standard requires certification bodies to institute an ongoing systematic process to ensure that the certification is updated and remains market relevant as skill sets change. Quality improvement processes should be embedded throughout the certification programme.

\section{Discussion and Implication for Workforce Development}

Employers are moving away from a degree based hiring to competency-based hiring especially in industries struggling to find talent. For instance, the Japan Business Federation has reached a formal decision to abolish the uniform recruiting schedule for new hires among its member companies (Ishikura, 2018). This decision is expected to make hiring by not only Japanese companies more flexible and impact the degree-based hiring that in the past assured a 'job for life'. The U.K. office of accounting firm Ernst \& Young stopped requiring new hires to have a college degree in 2016 after an internal study found little correlation between academic success and job performance. It is only a matter of time before employers in other countries move away from degree-based hiring to skill-based hiring.

The current education system globally is going through disruption in light of alternate ways to acquire knowledge and skills based on cutting-edge technological initiatives like massive online open courses (MOOCs). In the education world, there is a shift towards competency-based learning, which is an outcome-based approach to education. Under this approach, the amount of time that is spent on a learning event is not as significant as what the student has learned. The proposed outcome-focused framework has the potential to bridge the chasm between credit-bearing and non-credit-bearing workforce education and make the credentials relevant to employers and learners. This framework could also drive the educational system toward industry responsive curricula that are aligned to better employment. Despite its weakness as a measure of learning, the credit hour has long been the standard academic yardstick for educational attainment. What is currently lacking is a standardized way of evaluating noncredit learning. This problem is likely to become accentuated in the coming years as more 
students turn to alternative ways to acquire knowledge. It should come as no surprise that the 'biggest university' for young millennials is YouTube and Instructables.com. There is a need to recognize, assess, and document non-credit learning so that it can take the form of an alternate credential. It is estimated that in the near future, non-credit learning will account for half of all post-secondary credentials. There is a need to connect these alternate pathways so that they result in a certificate, badge, or a micro-credential that augments the more traditional educational offerings.

In most developing countries, the state of education is far inadequate to meet the growing demands of a knowledge economy. Not only is the quality of education poor, but the coverage is also insufficient, and far too many children are deprived of basic education. According to a World Bank report, the quality and nature of the education process must change and outcomes improved to provide people with the 21 st-century skills needed for economic development (World Bank, 2003). By 2050, the labour force in Africa is projected to increase by 125 percent; in Latin America, by 26 percent, and in Asia by 22 percent. The main policy challenge is to ensure that growing population in developing countries have the skills to escape the poverty cycle and leverage the new opportunities that have emerged on account of globalization and technological innovation (Wang, 2012).

In an interconnected world, personnel certification is quickly becoming the new currency for acceptance of qualified persons. Just as the adoption of a single currency offers several advantages over each country having its currency, so too certifications that are based on validated global schemes help to foster closer economic co-operation and provide more opportunities for businesses to hire competent persons. People are moving across borders, and employers are looking for portable credentials. Global flows have served as a common factor in promoting economic growth since the Silk Road days. In today's knowledge era, the movement of people across borders has reached astronomical levels, leading to the emergence of a global village. According to the McKinsey Global Institute, in the next decade, the global flows will triple due to the spread of the internet and unprecedented technological innovations (McKinsey, 2014). The global flow of people offers tremendous opportunities and challenges to the expanding web of global interconnectedness. Economies that have a strong pool of human capital are poised to reap enormous returns by fostering investment and wealth creation in the new world. The growing interconnectedness of global economies and technological innovations has also created an environment ripe for the globalization of certifications. Certification is an important means of skills acquisition (Kuczera \& Field, 2013). The number of people seeking certification, worldwide, continues to grow. This growth is attributable to several benefits associated with certification. The certification programmes are for a shorter duration, focus on specific professional competencies, and are not subject to the formal procedures and requirements of a university degree programme. A certification programme offers tremendous flexibility in delivery, as technology has made it possible to provide an exam almost anywhere in the world. By focusing on evaluation/outcomes, certification allows a person to develop their skill by using traditional and non-traditional learning processes. A certification is an attractive option for working adults who do not have the time and resources to attend a regular educational degree. Certifications also serve as an instrument to assess prior learning without the limitation of 'seat time' based education. Also, certifications can respond quickly to changing industry needs and are particularly relevant in sectors with rapid changes in technology. This probably explains the rapid growth of certifications in the information technology arena. 
In a flattening world, where each country needs to ensure that the knowledge and skills of its workforce are constantly updated, the framework offers a novel approach for the workforce and national human development. From a practical perspective, the framework speaks to the need to foster an ecosystem of competency-based stacked credentials across different industrial and service sectors to develop the skills of the workforce, whose contribution is critical to economic growth. While there is a growing demand for skilled workers, many jobs remain unfilled due to the unavailability of competent persons. At the same time, millions of people cannot find jobs because they do not have the required competence. The proposed framework provides a means to bridge the skills gap and provide a burgeoning population with an opportunity to obtain credentials that will help them to get gainful employment. All economies whether developed or developing could use this framework to place a greater emphasis on outcomes-based learning that is aligned with industry-recognized competency.

\section{Implications and Directions for HRD}

Traditionally, human resource development has been defined at the individual, group, and organizational levels. However, there is "a rapidly emerging emphasis on HRD defined as national agenda, often in the past labelled as manpower planning or human capital investment" (McLean, 2004, p. 269). The idea of HRD at a national level is relatively new. The proposed framework incorporates all types of credentials and links them with industry-recognized certifications. This framework presents a model of personnel certification based on HRD principles and includes (a) education in courses aligned with professional rubrics, (b) experience executing professional-level practice, (c) passing one or more rigorous examination and, (d) maintenance of competencies through continuing education. Furthermore, the framework incorporates both formal and informal aspects of learning.

The HRD discipline is unique as it brings a holistic perspective to integrate formal and informal learning with work experiences and evaluations to develop occupational skills. This approach has the added advantage of anchoring the solutions to workforce development in an established theoretical and research framework around distinctive learning needs of adult students and taking advantage of their real-world experiences. HRD has also championed the cause of underprepared and low skill adults without the education and competence for full participation in society. The existing educational pathways more commonly known as developmental education for low-income worker learners is a significant roadblock to programme completion. Despite the growing importance of education and increased access to learning resources, there is an increase in the number of people with inadequate employable skills. The HRD perspective can help bridge the gap between those with and without formal education and skills by offering an alternate non-linear route for skill acquisition. In turn, enhanced pathways for skill acquisition will create greater social and economic opportunities for millions of people both in developed and developing economies. HRD research can contribute more to the developmental policies by examining the impact of the proposed framework on workforce development. HRD's contribution to workforce development would be significant given its expertise in a systems approach to institutional design, learner-centred instructional strategies, and organizational change. It will also provide HRD researchers with expertise in workforce development an opportunity to examine the effectiveness of a credentialing framework to support NHRD. With the growing importance of workforce development, HRD researchers and practitioners with their unique expertise and worldview have a unique opportunity to contribute in this area. More importantly, 
as President J.F. Kennedy would say, the reason to do so is not that it is easy but that it is hard and critical for human development.

\section{References}

American Board of Nursing Specialties (2005). A position paper on the value of specialty certification. Available at https://hes32-ctp.trendmicro.com:443/wis/clicktime/v1/query?url=http $\% 3 \mathrm{a} \% 2 \mathrm{f} \% 2 \mathrm{fwww}$. nursingcertification.org $\% 2$ fresources $\% 2$ fDocuments $\% 2$ fresearch $\% 2$ fvalue $\% 5$ fcertification. pdf\&umid $=6 \mathrm{f} 38 \mathrm{c} 499-7769-4 \mathrm{bc} 0-\mathrm{a} 806-00370 \mathrm{~d} 0 \mathrm{af} 496 \&$ auth $=768 \mathrm{f} 192 \mathrm{bba} 830 \mathrm{~b} 801 \mathrm{fed} 4 \mathrm{f} 40 \mathrm{fb} 360 \mathrm{f} 4 \mathrm{~d} 13$ 74fa7c-52a8bce2c938b192929ee51f94b1f20a7a3800a1

Anand, S., \& Sen, A. (2000). Human development and economic sustainability. World Development, 28(12), 2029-2049.

Belfield, C. R., \& Bailey, T. (2011). The benefits of attending a community college: A review of the evidence. Community College Review, 39(1), 46-68.

Carter, S. D. (2005). The growth of supply and demand of occupational-based training and certification in the United States, 1990-2003. Human Resource Development Quarterly, 16(1), 33-54.

Chapman, J., Conlon, G., \& Muller, P. (2008). An economic impact assessment of the CCPMO. London: Chartered Management Institute. Retrieved from https://londoneconomics.co.uk/wp-content/ uploads/2011/09/43-Economic-benefit-of-the-Consultative-Committee-for-Professional-ManagementOrganisations-CCPMO.pdf

Connecting Credentials (2016). Lessons from the national summit on credentialing and the next steps in the national dialogue. Retrieved from https:/www.luminafoundation.org/files/resources/lessons-fromnational-credentialing-summit.pdf

Corporation for a Skilled Workforce (2018). Making a market for competency-based credentials. Retrieved from http://skilledwork.org/wp-content/uploads/2013/12/MakingaMarketforCompetencyBasedCredentials.pdf

Cronen, S., McQuiggan, M., \& Isenberg, E. (2017). Adult Training and Education: Results from the National Household Education Surveys Program of 2016 (NCES 2017-103rev). National Center for Education Statistics, Institute of Education Sciences, U.S. Department of Education. Washington, DC. Retrieved from http://nces.ed.gov/pubsearch.

Drucker, Peter. (1999). Management challenges for the 21st Century. New York: Harper Collins.

Eisemon, N., \& Cline, A. (2006). The value of certification. Gastroenterology Nursing 29(6): 428-430.

Fakuda-Parr, S. (2003). The human development paradigm: Operationalizing Sen's ideas on capabilities. Feminist Economics 9(2), 301-317.

Fazekas, M., \& Field, S. (2013). A skills beyond school review of Switzerland. OECD Reviews of Vocational Education and Training. Retrieved from https://www.oecd-ilibrary.org/education/skills-beyond-schoolreview-of-switzerland 9789264062665 -en

Field, S., \& Kuczera, M. (2012). A skills beyond school commentary on Israel. OECD Review of Vocational Education and Training. Available at https://hes32-ctp.trendmicro.com:443/wis/clicktime/v1/ query?url=https $\% 3 \mathrm{a} \% 2 \mathrm{f} \% 2$ fwww.oecd.org $\% 2$ feducation $\% 2$ fskills $\% 2$ dbeyond $\% 2$ dschool $\% 2 \mathrm{fA} \% 252$ 0Skills\%2520Beyond\%2520School\%2520Commentary\%2520on\%2520Israel.pdf\&umid=6f38c4997769-4bc0-a806-00370d0af496\&auth=768f192bba830b801fed4f40fb360f4d1374fa 7c-4df37cd52e5e 9c3ce104585baeb303fe12a2b713

Fretwell, D., Lewis, M., \& Deij, A. (2001). A framework for defining and assessing occupational and training standards in developing countries. ERIC Clearinghouse on adult, career, and vocational education, Columbus, Ohio, World Bank, Washington, D.C., and European Training Foundation, Turin, Italy.

Gao, N. Gill, K., Schmidt L., \& Pratt, C. (2010). The application of human capital theory in vocational rehabilitation for individuals with mental illness. Journal of Vocational Rehabilitation 32, 25-33.

Gathmann, C., \& Schönberg, U.F. (2010). How general is human capital? A task-based approach. Journal of Labor Economics 28(1), 1-49. 
Goldin, C. (2001). The Human-Capital Century and American Leadership: Virtues of the Past. Journal of Economic History 61(2), 263-292.

Green, A., \& Hogarth, T. (2016). The UK skills system: how aligned are public policy and employer views of training provision? UK government's Foresight Future of Skills and Lifelong Learning project Science. Retrieved from https://assets.publishing.service.gov.uk/government/uploads/system/uploads/ attachment_data/file/571695/ER8_The_UK_skills_system_how_aligned_are_public_policy_and_ employer_views_of_training_provision.pdf

Hsu, Y., \& Yancey, G. B. (2015). The benefits of human resources certification. Emporia State Research Studies, 50(1), 1-10.

International Accreditation Forum (2017). IAF MLA Report-2017. Retrieved from https://www.iaf.nu/ upFiles/IAF\%20MLA\%202017.\%2024.8.18\%20Final\%20Med\%20res.pdf

International Organization for Standardization (2003). International standard ISO/IEC 17024 conformity assessment - general requirement for bodies operating certification of persons. Geneva, Switzerland: International Organization for Standardization.

Ishikura, Y. (2018, October 18). The need for a skill-based approach to jobs. The Japan Times, p. 8.

Krishna, V. (2014). Leveraging certification standards to promote the globalization of financial professionals. Investment and Wealth Monitor September-October: 36-37.

Kuczera, M., \& Field. S. (2013). A Skills beyond School Review of the United States, OECD Reviews of Vocational Education and Training, OECD Publishing. Retrieved from http://dx.doi. org/10.1787/9789264202153-en

McCarthy, M. A. (2016). Developing a National STEM Workforce Strategy: A Workshop Summary. National Academies Press.

McKinsey (2014). Global flows in a digital age: How trade, finance, people, and data connect the world economy. McKinsey Global Institute. Retrieved from https://www.mckinsey.com/ /media/McKinsey/ Featured\%20Insights/Globalization/Global\%20flows\%20in\%20a\%20digital\%20age/Global_flows_ in_a_digital_age_Full_report\%20March_2015.ashx

McLean, G. (2004). National human resource development: What in the world is it?. Advances in Developing Human Resources 6(3), 269-275.

McLean, G. (2014). National HRD. In Chalofsky, N., Rocco, T.S., \& Morris, M.L (Eds.), Handbook of Human Resource Development (pp. 643-660). Hoboken, N.J.: Wiley.

Psacharopoulos, G., \& Patrinos, H (2004). Returns on investment in education: A further update. Education Economics 12(2), 111-134.

Purcell, W. (2014). Employability is our job. Retrieved from https://www.insidehighered.com/ views/2014/06/13/essay-says-colleges-and-universities-should-be-judged-employability

Rexworthy, J. (2015). The Role of Sector Skills Councils in the UK Evolution and Roles in Industry Development. Federation for Industry Sector Skills and Standard. Retrieved from https://www. britishcouncil.ph/sites/default/files/jane_rexworthy_role_of_sector_skills_council.pdf

Samuelson, R. (2006). How we dummies succeed. Washington Post September 6.

Schultz, T. (1961). Investment in human capital. American Economic Review 51, 1-17.

Sen, A. (1989). Development as capabilities expansion. Journal of Development Planning 19, 41-58.

Sidorkin, A. (2007). Human capital and the labor of learning: A case of mistaken identity. Educational Theory 57(2), 159-170.

Smith, A. (1976). The wealth of nations. New York: P.F. Collier \& Son.

Torpey, E. (2016). Will I need a license or certification for my job? Retrieved from https://www.bls.gov/ careeroutlook/2016/article/will-i-need-a-license-or-certification.htm

Torraco, R. J. (2007). Low-skilled adults in the United States: A case of human resource underdevelopment. Human Resource Development Review 6(4), 343-352.

UNIDO (2018). Guidelines on conformity assessment- ISO/IEC 17024. Retrieved from https://www.unido. org/sites/default/files/files/2018-07/Guidelines_on_Conformity_Assessment.pdf

Wang, Y. (2012). Education in a changing world: Flexibility, skills, and employability. The World Bank. Retrieved from https://openknowledge.worldbank.org/bitstream/handle/10986/27092/691040WP00P UBL0ability0WEB050110120.pdf?sequence=1\&isAllowed=y 
Warner, C. (2000). Attracting, developing, and retaining top talent. Vital Speeches of the Day, 66(24), 751-753.

Weise, M. (2014). The real revolution in online education is not MOOCs. Retrieved from https://hbr. org/2014/10/the-real-revolution-in-online-education-isnt-moocs

Wheatley, M. J., \& Kellner-Rogers, M. (1996). A simpler way. San Francisco, CA: Berrett-Koehler.

World Bank (2003). Lifelong learning in the global knowledge economy: Challenges for developing economies. Retrieved from http://siteresources.worldbank.org/INTLL/Resources/Lifelong-Learningin-the-Global-Knowledge-Economy/lifelonglearning_GKE.pdf

Zanko, M., \& Ngui, M. (2003). The implications of supra-national regionalism for human resource management in the Asia-Pacific region. In The handbook of human resource management policies and practices in Asia-Pacific economies Mat. Zanko \& Michael. Ngui (Eds.), Vols. 1-2, pp. 5-22. Cheltenham, UK: Edward Elgar.

\section{The Author}

Dr. Vijay Krishna is the senior director, personnel credentialing accreditation programs at the American National Standards Institute (ANSI), Washington DC. He currently chairs the Pacific Accreditation Cooperation working group for personnel certification and International Accreditation Forum task group on competence of accreditation body assessors and experts. He works with various government and international agencies globally to implement personnel certification accreditation.

Dr. Krishna has served as an international consultant for the United Nations Industrial Development Organization and taught graduate-level courses in leadership, organizational change, and learning in adulthood at The George Washington University. He has also published in the Human Resource Development International, Advances in Human Resources, International Journal of Knowledge, Culture, and Change Management, Indian Management, and Economic Times. 